\title{
Corrigendum: Shifts in metabolic hydrogen sinks in the methanogenesis-inhibited ruminal fermentation: a meta-analysis
}

\author{
Emilio M. Ungerfeld * \\ Instituto de Investigaciones Agropecuarias (INIA) Carillanca, Temuco, Chile
}

Keywords: methanogenesis inhibition, Rumen, fermentation, metabolic hydrogen, meta-analysis, volatile fatty acids

\section{A Corrigendum on}

Shifts in metabolic hydrogen sinks in the methanogenesis-inhibited ruminal fermentation: a meta-analysis

by Ungerfeld, E. M. (2015). Front. Microbiol. 6:37. doi: 10.3389/fmicb.2015.00037

\section{OPEN ACCESS}

Edited and reviewed by: A. Murat Eren,

Marine Biological Laboratory, USA

*Correspondence:

Emilio M. Ungerfeld

emilio.ungerfeld@inia.c

Specialty section:

This article was submitted to

Systems Microbiology

a section of the journal

Frontiers in Microbiology

Received: 24 April 2015

Accepted: 15 May 2015

Published: 02 June 2015

Citation:

Ungerfeld EM (2015) Corrigendum: Shifts in metabolic hydrogen sinks in the methanogenesis-inhibited ruminal fermentation: a meta-analysis.

Front. Microbiol. 6:538.

doi: 10.3389/fmicb.2015.00538
I wish to point out a mistake I made in the Discussion section of Ungerfeld, E. M. (2015) Shifts in metabolic hydrogen sinks in the methanogenesis-inhibited ruminal fermentation: a metaanalysis. Front. Microbiol. 6:37. doi: 10.3389/fmicb.2015.00037, which was kindly pointed out to me by Dr. Stéphane Duval. When citing the articles by Martínez-Fernández et al. (2014) and Romero-Perez et al. (2014), I mistakenly confused nitrooxycompounds with nitrocompounds. Both Martínez-Fernández et al. (2014) and Romero-Perez et al. (2014) evaluated nitrooxycompounds, not nitrocompounds, in their work. I wish to acknowledge this mistake and thank Dr. Stéphane Duval for contacting me on this.

\section{References}

Martínez-Fernández, G., Abecia, L., Arco, A., Cantalapiedra-Hijar, G., Martín-García, A. I., Molina-Alcaide, E., et al. (2014). Effects of ethyl-3-nitrooxy propionate and 3-nitrooxypropanol on ruminal fermentation, microbial abundance, and methane emissions in sheep. J. Dairy Sci. 97, 3790-3799. doi: 10.3168/jds.2013-7398

Romero-Perez, A., Okine, E. K., McGinn, S. M., Guan, L. L., Oba, M., Duval, S. M., et al. (2014). The potential of 3nitrooxypropanol to lower enteric methane emissions from beef cattle. J. Anim. Sci. 92, 4682-4693. doi: 10.2527/jas. 2014-7573

Conflict of Interest Statement: The author declares that the research was conducted in the absence of any commercial or financial relationships that could be construed as a potential conflict of interest.

Copyright (c) 2015 Ungerfeld. This is an open-access article distributed under the terms of the Creative Commons Attribution License (CC BY). The use, distribution or reproduction in other forums is permitted, provided the original author(s) or licensor are credited and that the original publication in this journal is cited, in accordance with accepted academic practice. No use, distribution or reproduction is permitted which does not comply with these terms. 